\title{
Perbedaan Tanggap Morfologi Akar Galur Inbrida Sorgum pada Kondisi P Rendah
}

\section{Differences in Root Morphological Responses of Sorghum Inbred Lines in Low P Conditions}

\author{
Putri Andini Mandasari ${ }^{1}$, Desta Wirnas ${ }^{2}$, Trikoesoemaningtyas ${ }^{2}$, dan Didy Sopandie ${ }^{2 *}$ \\ ${ }^{1}$ Program Studi Agronomi dan Hortikultura, Sekolah Pascasarjana, Institut Pertanian Bogor \\ ${ }^{2}$ Departemen Agronomi dan Hortikultura, Fakultas Pertanian, Institut Pertanian Bogor \\ (Bogor Agricultural University), Jl. Meranti, Kampus IPB Darmaga, Bogor 16680, Indonesia
}

Diterima 6 Maret 2020/Disetujui 20 April 2020

\begin{abstract}
Plant root has various responses for adaptation under low P condition. This study aims to observe information on root morphology responses from sorghum inbred lines under low $P$ condition. This experiment used a randomized complete block design nested with two factors, namely genotype and P fertilizer dosage. The genotype consisted of 11 sorghum inbred lines (RIL-F8), B-69 (susceptible check), Numbu (tolerant check), and two national varieties (WHP and Kawali). Fertilizer dosage used a dose of sufficient $P\left(66.76 \mathrm{~kg} \mathrm{ha}^{-1} \mathrm{P}_{2} \mathrm{O}_{5}\right)$ and a dose of low $P\left(33.38 \mathrm{~kg} \mathrm{ha} a^{-1} P_{2} \mathrm{O}_{5}\right)$. The result showed there were differences in root morphological response between inbred lines (RIL-F8) sorghum under low $P$ conditions. The tolerant lines had a higher character of the longest root length $(41.33-61.87 \mathrm{~cm})$, root volume $(8.87-12.87 \mathrm{~mL})$, root diameter $(0.88-1.02$ $\mathrm{mm}$ ), and proteoid root total (2.4-4.0) as compared to sensitive lines In low P condition. These characters associated with the high biomass of tolerant lines in low P conditions, therefore it could be used as an important character for the selection of root adaptation in low $P$ conditions.
\end{abstract}

Keywords: proteoid root, biomass, phosphorus, tolerant

\section{ABSTRAK}

Akar tanaman memiliki respon yang bervariasi sebagai bentuk adaptasi pada kondisi Prendah. Penelitian ini bertujuan untuk memperoleh informasi tanggap morfologi akar dari galur-galur inbrida sorgum pada kondisi P rendah. Percobaan ini menggunakan rancangan kelompok lengkap teracak (RKLT) tersarang dua faktor yaitu genotipe dan dosis pupuk P. Genotipe yang digunakan terdiri atas 11 galur inbrida sorgum (RIL-F8), tetua peka (B-69), tetua toleran (Numbu) dan 2 varietas nasional (WHP dan Kawali). Dosis pupuk yang digunakan terdiri atas dosis $\mathrm{P}$ cukup $\left(66.76 \mathrm{~kg} \mathrm{ha}^{-1} \mathrm{P}_{2} \mathrm{O}_{5}\right)$ dan $\mathrm{P}$ rendah (33.38 $\left.\mathrm{kg} \mathrm{ha}^{-1} P_{2} \mathrm{O}_{5}\right)$. Hasil penelitian menunjukkan bahwa terdapat perbedaan tanggap morfologi akar di antara galur-galur inbrida (RIL-F8) sorgum pada kondisi P rendah. Galur-galur toleran memiliki panjang akar terpanjang $(41.33-61.87 \mathrm{~cm})$, volume akar $(8.87-12.87 \mathrm{~mL})$, diameter akar terpanjang $(0.88-1.02 \mathrm{~mm})$ dan jumlah akar proteoid (2.4-4.0) yang lebih tinggi dibandingkan galur-galur peka pada kondisi P rendah. Karakter-karakter tersebut mendukung tingginya biomassa galur toleran pada kondisi P rendah, sehingga menjadi karakter penting untuk seleksi adaptasi akar pada kondisi P rendah.

Kata kunci: akar proteoid, biomassa, fosfor, toleran

\section{PENDAHULUAN}

Pemanfaatan lahan kering di Indonesia banyak diarahkan untuk pengembangan tanaman pangan yang mempunyai daya adaptasi luas terhadap berbagai cekaman abiotik. Lahan kering seperti lahan masam memiliki faktor penghambat pertumbuhan tanaman karena unsur-unsur makro seperti P difiksasi oleh $\mathrm{Al}$ menjadi kompleks AlP. Hal tersebut menyebabkan defisiensi P pada tanah dan

\footnotetext{
* Penulis untuk korespondensi. e-mail: d_sopandie@ipb.ac.id
}

tanaman (Marschner, 2012). Tanaman memiliki bentuk adapatasi yang berbeda untuk dapat menyerap hara yang mobile terutama unsur P. Deng et al. (2020) melaporkan bahwa pada kondisi P rendah akar memiliki respon yang berbeda sebagai bentuk toleransi terhadap $P$ rendah.

Tanaman toleran defisiensi P mempunyai gen yang mampu meningkatkan pertumbuhan awal akar dan poliferasi akar (Gumayo et al., 2012). Hal tersebut mendukung kemampuan tanaman dalam menyerap P lebih banyak pada kondisi defisiensi P. Niu et al. (2013) menyatakan bahwa pada kondisi defisiensi $\mathrm{P}$, tanaman menunjukkan berbagai bentuk adaptasi salah satunya dengan modifikasi morfologi/ 
sistem arsitektur akar. Vejchasarn et al. (2016) menyatakan bahwa sistem perakaran merupakan organ utama untuk penyerapan hara, perubahan morfologi, dan fisiologi akar menjadi sangat penting dalam penyerapan dan penggunaan yang efektif pada kondisi fosfor rendah.

Adaptasi morfologi akar pada kondisi defisiensi P telah dilaporkan pada beberapa penelitian seperti peningkatan akar lateral pada jagung (Jia et al., 2018), panjang akar spesifik pada gandum (Nobile et al., 2019), diameter akar pada sorgum (Bernardino et al., 2019) dan pembentukan akar klaster pada lupin (Wang et al., 2019). Miguel et al. (2015) menyatakan bahwa perubahan morfologi akar pada tanaman seperti panjang akar dilakukan sebagai upaya peningkatan perolehan P di tanah. Berdasarkan hal ini, morfologi akar menjadi hal penting untuk diketahui terutama sebagai karakter toleransi pada kondisi defisiensi P.

Sorgum tergolong tanaman legume yang dapat dijadikan sebagai pangan (grain) dan pakan (forage) (Bean et al., 2013), serta toleran pada berbagai cekaman abiotik (Ongom et al., 2016; Lestari et al., 2017, Rui-Dong, 2018; Luna et al., 2018). Pada penelitian sebelumnya, Momongan et al. (2019) memperoleh 11 galur inbrida sorgum toleran terhadap P tanah rendah berdasarkan bobot biji per malai, namun tanggap morfologi akar sebagai bentuk adaptasinya terhadap P rendah belum diketahui. Penelitian ini bertujuan untuk memperoleh informasi tanggap morfologi akar galur inbrida sorgum pada kondisi $\mathrm{P}$ rendah dan hubungannya dengan biomassa yang dihasilkan.

\section{BAHAN DAN METODE}

Penelitian dilaksanakan di Kebun Percobaan Pendidikan Cikabayan IPB, Darmaga, Bogor. Percobaan ini menggunakan pot dari paralon dengan alas polibag kemudian diisi tanah dan dibiarkan \pm 2 pekan sampai siap tanam. Berdasarkan hasil analisis tanah diketahui bahwa $\mathrm{pH}$ sebesar 4.80, $\mathrm{P}$ tersedia tergolong sangat rendah yaitu 0.99 ppm $\mathrm{P}_{2} \mathrm{O}_{5}$, dan $\mathrm{P}$ total $33.51 \mathrm{mg} \mathrm{P}_{2} \mathrm{O}_{5} / 100 \mathrm{~g}$. Curah hujan bulanan di daerah penelitian (bulan Januari sampai Maret 2019) $\pm 294.2 \mathrm{~mm} / \mathrm{bl}$. Rata-rata suhu udara selama penelitian adalah $30.8^{\circ} \mathrm{C}$ (maksimum) dan $23.2^{\circ} \mathrm{C}$ (minimum) dengan intensitas cahaya matahari sekitar $451 \mathrm{Cal} / \mathrm{cm}^{2}$ (BMKG, Darmaga Bogor).
Bahan genetik yang digunakan dalam penelitian ini adalah galur-galur inbrida (RIL-F8) sorgum hasil persilangan B-69 dengan Numbu, tetua peka (B-69), tetua toleran (Numbu) dan 2 varietas nasional (WHP dan Kawali) (Tabel 1). Percobaan ini menggunakan rancangan kelompok lengkap teracak (RKLT) tersarang dua faktor yaitu genotipe dan dosis pupuk P. Dosis pupuk terdiri atas dosis P cukup dan $P$ rendah. Pot percobaan pada kondisi P cukup diberikan pupuk $\mathrm{P}$ sesuai dosis rekomendasi pemupukan menurut Whitney (1998) sebesar $66.76 \mathrm{~kg} \mathrm{ha}^{-1} \mathrm{P}_{2} \mathrm{O}_{5}$ (185.45 kg ha-1 SP36) sedangkan pot pada kondisi $\mathrm{P}$ rendah diberikan setengah dosis dari rekomendasi pemupukan pada kondisi $\mathrm{P}$ cukup yaitu sebesar $33.38 \mathrm{~kg} \mathrm{ha}^{-1} \mathrm{P}_{2} \mathrm{O}_{5}\left(92.72 \mathrm{~kg} \mathrm{ha}^{-1} \mathrm{SP} 36\right)$. Percobaan menggunakan 3 ulangan sehingga terdapat 90 unit percobaan.

Tahapan percobaan dimulai dari pengisian tanah pada pot paralon berukuran panjang $\pm 35 \mathrm{~cm}$ dan diameter $\pm 12 \mathrm{~cm}$ yang telah dialasi polibag. Selanjutnya dilakukan penanaman setelah tanah dibiarkan \pm 2 pekan. Pemupukan dilakukan saat penanaman meliputi pupuk Urea $50 \mathrm{~kg} \mathrm{ha}^{-1}$, SP36 $185.45 \mathrm{~kg} \mathrm{ha}^{-1}$ (lahan P cukup) dan $92.72 \mathrm{~kg} \mathrm{ha}^{-1}$ (lahan $\mathrm{P}$ rendah) serta $\mathrm{KCl} 100 \mathrm{~kg} \mathrm{ha}^{-1}$. Pengamatan morfologi akar dilakukan secara destruktif dengan merobek polibag dan merendam paralon dalam bak air untuk memudahkan dalam pembersihan akar yang akan diamati. Pengamatan dilakukan saat stadia vegetatif awal yaitu 5 daun menurut stadia pertumbuhan Vanderlip dan Reeves (1972), dalam penelitian ini sekitar 5 minggu setelah tanam. Peubah yang diamati meliputi 1) panjang akar terpanjang, diukur dari pangkal sampai ujung pada akar terpanjang; 2) diameter akar terpanjang, diukur pada bagian diameter terbesar dari akar terpanjang; 3) volume akar, diukur dengan cara memasukkan akar yang telah dikeringanginkan pada gelas ukur yang terisi air penuh kemudian menghitung volume air yang tumpah sebagai volume akar; 4) jumlah akar proteoid, dihitung jumlah akar proteoid yang terbentuk, yaitu akar tanaman yang membentuk kelompok akar lateral yang pendek atau pertumbuhan akar lateral yang menggerombol atau membentuk klaster; 5) bobot kering akar, diukur dengan menimbang akar yang telah di oven pada suhu $60^{\circ} \mathrm{C}$ selama $2 \times 24$ jam; 6) bobot kering tajuk, diukur dengan menimbang tajuk yang telah di oven pada suhu $60{ }^{\circ} \mathrm{C}$ selama $2 \times 24$ jam; 7) bobot kering total; 8) rasio akar:tajuk.

Tabel 1. Daftar galur-galur inbrida (RIL F8) sorgum dan pembanding yang diuji

\begin{tabular}{llllll}
\hline No & Galur-galur & Identifikasi & No & Galur-galur & Identifikasi \\
\hline 1 & B-69/N 104-7 & Toleran & 9 & B-69/N 48-8 & Peka \\
2 & B-69/N 114-7 & Toleran & 10 & B-69/N 67-9 & Peka \\
3 & B-69/N 151-8 & Toleran & 11 & B-69/N 110-6 & Peka \\
4 & B-69/N 115-9 & Toleran & 12 & B-69 & Tetua peka \\
5 & B-69/N 331-8 & Toleran & 13 & Numbu & Tetua toleran \\
6 & B-69/N 286-6 & Toleran & 14 & Kawali & Varietas nasional \\
7 & B-69/N 170-9 & Toleran & 15 & Watar Hammu Putih & Varietas nasional \\
8 & B-69/N 177-4 & Peka & & & \\
\hline
\end{tabular}


Data yang diperoleh dianalisis ragam per lingkungan kemudian dilanjutkan dengan LSD taraf 5\%. Data juga dianalisis korelasi untuk mengetahui keratan hubungan antar peubah.

\section{HASIL DAN PEMBAHASAN}

Rekapitulasi analisis ragam pengaruh genotipe terhadap tanggap morfologi akar pada kondisi P cukup dan $\mathrm{P}$ rendah ditampilkan pada Tabel 2. Hasil analisis ragam menunjukkan bahwa pada kondisi P cukup, perlakuan galurgalur inbrida sorgum berpengaruh tidak nyata terhadap karakter panjang akar terpanjang, volume akar, diameter akar terpanjang, jumlah akar proteoid, bobot kering akar, bobot kering tajuk, bobot kering total dan rasio akar:tajuk sedangkan pada kondisi $\mathrm{P}$ rendah menunjukkan pengaruh yang nyata untuk karakter-karakter tersebut. Sejalan dengan Deng et al. (2020) yang menyatakan bahwa pada kondisi $\mathrm{P}$ rendah tanaman memiliki respon morfologi akar yang berbeda sebagai bentuk toleransi terhadap P rendah.

Tabel 3 menunjukkan bahwa pada kondisi $\mathrm{P}$ rendah galur-galur toleran memiliki panjang akar terpanjang lebih tinggi dibandingkan dengan tetua peka, terutama galur toleran B-69/N 286-6 yang memiliki panjang akar terpanjang lebih tinggi dibandingkan dengan semua pembanding. Pada kondisi yang sama, galur-galur peka menunjukkan panjang akar terpanjang lebih rendah dibandingkan tetua toleran dan dua varietas nasional yaitu Kawali dan WHP. Hal ini menunjukkan bahwa pada kondisi P rendah galur toleran memiliki performa panjang akar yang lebih baik dibandingkan galur-galur peka. Sama halnya dengan jagung, Jiang et al. (2017) menyatakan bahwa pada kondisi defisiensi $\mathrm{P}$ galur toleran memiliki panjang akar lebih panjang dibandingkan galur peka. Péret et al. (2014) menyatakan terdapat hambatan pemanjangan akar primer yang disebabkan oleh pengurangan pemanjangan sel dan berhentinya poliferasi sel secara progresif dalam meristem akar pada kondisi defisiensi $\mathrm{P}$, seperti yang ditunjukkan galur-galur peka dalam penelitian ini.
Berdasarkan volume akar pada kondisi $\mathrm{P}$ rendah, secara keseluruhan galur-galur toleran memiliki volume akar lebih tinggi dibandingkan tetua peka, terutama galur toleran B-69/N 286-6 juga menunjukkan volume akar lebih tinggi dari varietas nasional Kawali. Pada kondisi yang sama, galur-galur peka menunjukkan volume akar lebih rendah dibandingkan tetua toleran dan varietas nasional WHP (Tabel 3). Hal ini menunjukkan bahwa galur-galur toleran memiliki volume akar lebih tinggi dibandingkan galur-galur peka, sehingga karakter volume akar dapat dijadikan sebagai bentuk adaptasi tanaman dalam kondisi defisiensi P. Pada sorgum, Camacho et al. (2002) menyatakan bahwa volume akar semakin kecil saat tanaman mengalami defisiensi $\mathrm{P}$, namun pada tanaman toleran (volume akar konsisten antara kondisi P cukup dan defisiensi P) morfologi akar yang dimiliki lebih tebal sehingga dapat mengambil $\mathrm{P}$ lebih baik dari dalam tanah. Pada gandum saat kondisi $\mathrm{P}$ rendah, Nguyen dan Stangoulis (2019) menyatakan terdapat penurunan volume akar lebih rendah pada genotipe yang teridentifikasi efisien dalam penggunaan $\mathrm{P}$ dibandingkan genotipe yang tidak efisien.

Pada kondisi $\mathrm{P}$ rendah, galur-galur toleran, kecuali galur B-69/N 331-8 menunjukkan diameter akar terpanjang lebih besar dibandingkan tetua peka, sebaliknya galurgalur peka menunjukkan diameter akar terpanjang yang lebih rendah dibandingkan tetua toleran dan dua varietas nasional Kawali dan WHP. Hal ini menunjukkan bahwa pada kondisi P rendah galur-galur toleran memiliki diameter akar terpanjang yang lebih tinggi dibandingkan galur-galur peka (Tabel 3). Bernardino et al. (2019) menyatakan bahwa peningkatan diameter akar akan mendukung penyerapan hara terutama pada kondisi defisiensi P sehingga mendukung peningkatan hasil. Agustina et al. (2010) melaporkan bahwa diameter akar mempengaruhi penyerapan hara sehingga akan berpengaruh terhadap pembentukan biomassa.

Berdasarkan karakter jumlah akar proteoid, pada kondisi P rendah galur-galur toleran memiliki jumlah akar proteoid lebih tinggi dibandingkan tetua peka, terutama galur B-69/N 151-8, B-69/N 286-6 dan B-69/N 170-

Tabel 2. Rekapitulasi sidik ragam pengaruh genotipe terhadap komponen morfologi akar pada kondisi $\mathrm{P}$ cukup dan $\mathrm{P}$ rendah

\begin{tabular}{lrrrc}
\hline \multirow{2}{*}{ Peubah } & \multicolumn{2}{c}{ Kondisi P cukup } & \multicolumn{2}{c}{ Kondisi P rendah } \\
\cline { 2 - 5 } & KT Galur & KK $(\%)$ & KT Galur & KK $(\%)$ \\
\hline Panjang akar terpanjang & 121.521 & 25.81 & $430.1374^{*}$ & 18.21 \\
Volume akar & 12.416 & 27.93 & $35.9328^{*}$ & 32.40 \\
Diameter akar & 0.018 & 18.72 & $0.1117^{*}$ & 18.55 \\
Jumlah akar proteoid & 0.467 & 34.19 & $5.6127^{*}$ & 32.08 \\
Bobot kering akar & 0.037 & 41.85 & $0.2865^{*}$ & 25.84 \\
Bobot kering tajuk & 0.181 & 34.56 & $1.3698^{*}$ & 30.46 \\
Bobot kering total & 0.274 & 35.47 & $2.7790^{*}$ & 25.69 \\
Rasio akar:tajuk & 0.018 & 22.18 & $0.1207^{*}$ & 33.17 \\
\hline
\end{tabular}

Keterangan: * = berpengaruh nyata terhadap peubah yang diamati 
9 juga menunjukkan jumlah akar proteoid lebih tinggi dibandingkan varietas nasional WHP dan Kawali. Hal tersebut berbeda dengan galur-galur peka yang memiliki jumlah akar proteoid lebih rendah dibandingkan tetua toleran dan kedua varietas nasional WHP dan Kawali (Tabel 3). Hal tersebut menunjukkan galur-galur toleran mampu membentuk akar proteoid yang lebih banyak dibandingkan galur peka pada kondisi P rendah. Akar proteoid merupakan pertumbuhan akar yang membentuk satu atau lebih kelompok dan memiliki jarak akar lateral yang berdekatan dengan pertumbuhan terbatas (Gambar 1). Pembentukan atau formasi akar proteoid merupakan mekanisme adaptasi spesial yang berkembang di lingkungan dengan ketersediaan unsur yang rendah (Shane dan Lambers, 2005). Rath et al. (2010) menyatakan perkembangan akar proteoid sebagian besar telah diselidiki pada kondisi defisiensi P. Wasaki et al. (2018) melaporkan bahwa akar proteoid (akar klaster) tidak hanya ditemukan pada kondisi defisiensi $\mathrm{P}$ namun juga terbentuk pada kondisi defisiensi $\mathrm{N}$.

Tabel 4 menunjukkan bahwa pada kondisi $\mathrm{P}$ rendah, galur-galur toleran memiliki bobot kering akar lebih tinggi dibandingkan tetua peka, terutama galur toleran B-69/N 286-6 juga menunjukkan bobot lebih tinggi dibandingkan semua pembanding. Hal berdeda ditunjukkan oleh galurgalur peka yang memiliki bobot kering akar lebih rendah dibandingkan tetua toleran dan varietas WHP. Hal ini menunjukkan bahwa galur-gaur toleran memiliki bobot yang lebih tinggi dibandingkan galur-galur peka. Tingginya bobot kering akar dari galur toleran diduga karena memiliki karakter morfologi akar seperti panjang akar terpanjang, diameter akar, volume akar dan jumlah akar proteoid lebih tinggi dibandingkan galur peka sehingga bobot yang dihasilkan juga lebih tinggi. Pada tanaman jagung, Jiang et al. (2017) menyatakan bahwa galur toleran menunjukkan biomassa akar yang lebih tinggi dibandingkan galur peka pada kondisi $\mathrm{P}$ rendah karena didukung oleh karakter akar seperti panjang akar lebih panjang, luas permukaan akar dan volume akar lebih tinggi.

Seluruh galur toleran pada kondisi $\mathrm{P}$ rendah menunjukkan bobot kering tajuk lebih tinggi dibandingkan tetua peka dan beberapa galur toleran juga menunjukkan bobot lebih tinggi dibandingkan varietas nasional WHP dan Kawali. Pada kondisi yang sama, galur-galur peka menunjukkan bobot kering tajuk lebih rendah dibandingkan tetua toleran, WHP dan sebagian juga dengan Kawali (Tabel 4). Seperti galur peka dalam penelitian ini, Camacho et al. (2002) menyatakan bahwa tanaman mengalami penurunan bobot kering tunas saat kondisi defisiensi P. Pada kondisi $\mathrm{P}$ rendah galur-galur toleran menunjukkan bobot lebih tinggi dibandingkan tetua peka, terutama galur B-69/N 286-

Tabel 3. Panjang akar terpanjang (PAT), volume akar (VA), diameter akar terpanjang (DAT) dan jumlah akar proteoid (JAP) dari galur inbrida sorgum pada kondisi $\mathrm{P}$ cukup dan $\mathrm{P}$ rendah

\begin{tabular}{lcccccccc}
\hline \multirow{2}{*}{ Galur } & \multicolumn{2}{c}{ PAT $(\mathrm{cm})$} & \multicolumn{2}{c}{ VA $(\mathrm{mL})$} & \multicolumn{2}{c}{ DAT $(\mathrm{mm})$} & \multicolumn{2}{c}{ JAP } \\
\cline { 2 - 8 } & $+\mathrm{P}$ & \multicolumn{1}{c}{$-\mathrm{P}$} & $+\mathrm{P}$ & $-\mathrm{P}$ & $+\mathrm{P}$ & $-\mathrm{P}$ & $+\mathrm{P}$ & $-\mathrm{P}$ \\
\hline B-69/N 104-7 (T) & 31.67 & $56.00 \mathrm{acd}$ & 8.73 & $9.50 \mathrm{a}$ & 0.99 & $0.89 \mathrm{a}$ & 3.33 & $2.7 \mathrm{a}$ \\
B-69/N 114-7 (T) & 44.00 & $41.33 \mathrm{a}$ & 7.60 & $9.30 \mathrm{a}$ & 0.92 & $0.88 \mathrm{a}$ & 3.00 & $2.7 \mathrm{a}$ \\
B-69/N 151-8 (T) & 44.33 & $46.50 \mathrm{a}$ & 8.23 & $9.93 \mathrm{a}$ & 1.13 & $0.93 \mathrm{a}$ & 3.67 & $3.7 \mathrm{ad}$ \\
B-69/N 115-9 (T) & 41.00 & $52.33 \mathrm{a}$ & 10.36 & $9.90 \mathrm{a}$ & 0.91 & $0.88 \mathrm{a}$ & 3.00 & $2.3 \mathrm{a}$ \\
B-69/N 331-8 (T) & 52.00 & $49.00 \mathrm{a}$ & 7.17 & $8.87 \mathrm{a}$ & 0.87 & 0.83 & 3.00 & $2.7 \mathrm{a}$ \\
B-69/N 286-6 (T) & 47.83 & $61.87 \mathrm{abcd}$ & 10.07 & $12.87 \mathrm{ad}$ & 1.06 & $1.02 \mathrm{a}$ & 2.67 & $4.0 \mathrm{ad}$ \\
B-69/N 170-9 (T) & 42.00 & $48.00 \mathrm{a}$ & 10.40 & $9.23 \mathrm{a}$ & 1.08 & $0.99 \mathrm{a}$ & 3.67 & $3.7 \mathrm{acd}$ \\
B-69/N 177-4 (P) & 44.00 & $27.67 \mathrm{bcd}$ & 10.90 & $3.10 \mathrm{bc}$ & 0.93 & $0.47 \mathrm{bcd}$ & 2.33 & $1.0 \mathrm{~b}$ \\
B-69/N 48-4 (P) & 57.00 & $26.33 \mathrm{bcd}$ & 10.47 & $3.47 \mathrm{bc}$ & 0.96 & $0.55 \mathrm{bcd}$ & 3.33 & $0.3 \mathrm{bcd}$ \\
B-69/N 67-9 (P) & 48.50 & $24.83 \mathrm{bcd}$ & 14.37 & $2.93 \mathrm{bc}$ & 0.95 & $0.49 \mathrm{bcd}$ & 3.00 & $0.0 \mathrm{bcd}$ \\
B-69/N 110-6 (P) & 45.00 & $32.00 \mathrm{~b}$ & 11.13 & $3.50 \mathrm{bc}$ & 1.04 & $0.56 \mathrm{bd}$ & 2.67 & $0.0 \mathrm{bcd}$ \\
B-69 (TP) & 43.67 & 23.67 & 11.17 & 3.10 & 0.87 & 0.62 & 3.67 & 0.3 \\
Numbu (TT) & 44.00 & 47.33 & 11.10 & 10.20 & 0.93 & 0.94 & 3.00 & 2.7 \\
WHP (VN) & 38.67 & 41.00 & 11.17 & 11.23 & 0.94 & 0.8 & 3.33 & 1.7 \\
Kawali (VN) & 55.33 & 40.67 & 14.13 & 6.07 & 1.01 & 0.94 & 3.33 & 1.7 \\
\hline P-value & 0.5770 & 0.0000 & 0.1942 & 0.0000 & 0.8910 & 0.0001 & 0.9603 & 0.0000 \\
CV (\%) & 25.81 & 18.21 & 27.93 & 32.40 & 18.72 & 18.55 & 34.19 & 32.08 \\
LSD & - & 12.56 & - & 4.09 & - & 0.24 & - & 1.05 \\
\hline
\end{tabular}

Keterangan: $\mathrm{a}=$ berbeda nyata menurut uji lanjut LSD pada taraf $5 \%$ dengan pembanding B-69; $\mathrm{b}=$ berbeda nyata menurut uji lanjut LSD pada taraf 5\% dengan pembanding Numbu; $\mathrm{c}=$ berbeda nyata menurut uji lanjut LSD pada taraf $5 \%$ dengan pembanding WHP; dan $\mathrm{d}=$ berbeda nyata menurut uji lanjut LSD pada taraf $5 \%$ dengan pembanding Kawali; $+\mathrm{P}=\mathrm{P}$ cukup; $-\mathrm{P}=\mathrm{P}$ rendah; $\mathrm{TT}=$ tetua toleran; $\mathrm{TP}=$ tetua peka; $\mathrm{VN}=$ Varietas nasional 


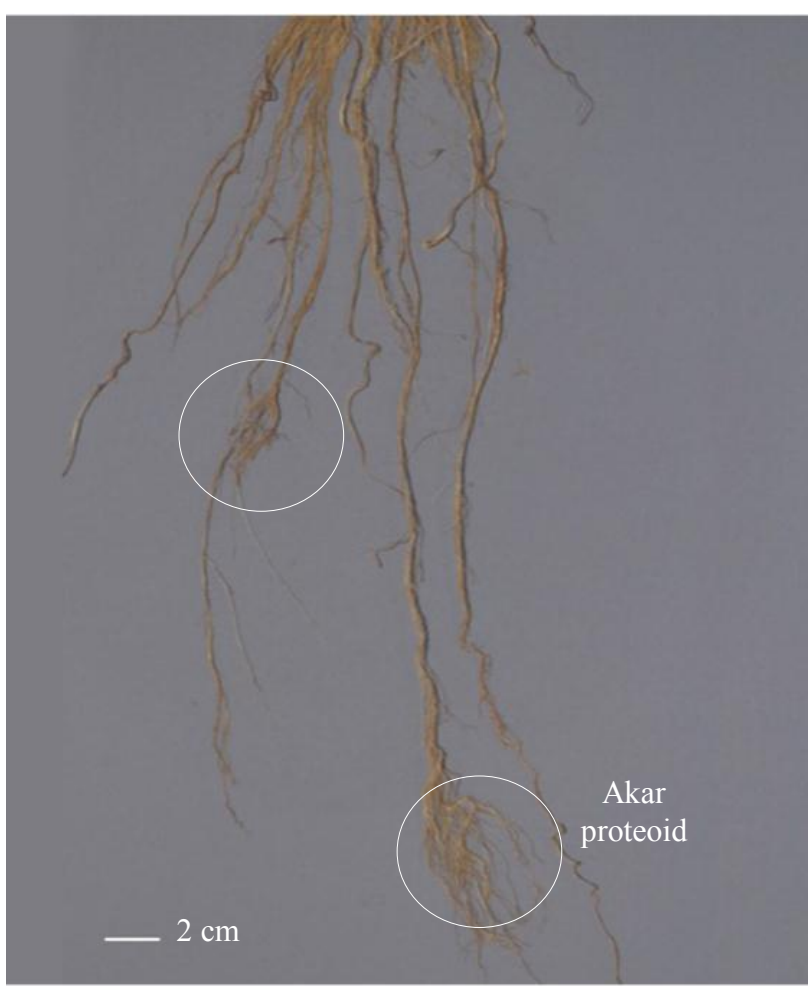

Gambar 1. Akar proteoid pada galur toleran
6 memiliki bobot kering total lebih tinggi dibandingkan semua pembanding. Galur peka pada kondisi yang sama menunjukkan bobot kering lebih rendah dibandingkan tetua toleran dan WHP. Hal tersebut menunjukkan bahwa galur toleran memiliki kemampuan membentuk bobot kering total yang lebih tinggi dibandingkan galur peka. Tingginya bobot kering total galur toleran diduga karena bobot kering dari akar dan tajuk yang dihasilkan juga tinggi. Berdasarkan rasio akar:tajuk pada kondisi P rendah menunjukkan bahwa tidak terdapat perbedaan antara galur-galur toleran dan peka dengan semua pembanding kecuali galur peka B-69/ N 177-4 dan B-69/N 67-9 yang menunjukkan rasio akar: tajuk lebih tinggi dibandingkan galur lainnya. Tingginya rasio akar:tajuk galur peka B-69/N 177-4 dan B-69/N 679 menunjukkan tingginya hasil fotosintat dari daun yang ditraslokasikan ke bagian akar. Hal ini menunjukkan bahwa galur peka tidak efisien karena biomassa akar dan biomassa tajuk yang dibentuk lebih rendah dibandingkan galur-galur toleran.

Korelasi karakter morfologi akar terhadap biomassa dari galur inbrida sorgum ditampilkan pada Tabel 5 dan 6 . Tabel 5 menunjukkan bahwa pada kondisi P cukup karakter morfologi akar yang memiliki korelasi positif dengan biomassa secara berurutan adalah volume akar, jumlah akar proteoid dan diameter akar terpanjang. Hal ini menunjukkan

Tabel 4. Bobot kering tajuk (BKT), bobot kering akar (BKA), bobot kering total (BKTO) dan rasio akar per tajuk (RAT) dari galur inbrida sorgum pada kondisi P cukup dan P rendah

\begin{tabular}{|c|c|c|c|c|c|c|c|c|}
\hline \multirow{2}{*}{ Galur } & \multicolumn{2}{|c|}{ BKT } & \multicolumn{2}{|c|}{ BKA } & \multicolumn{2}{|c|}{ BKTO } & \multicolumn{2}{|c|}{ RAT } \\
\hline & $+\mathrm{P}$ & $-\mathrm{P}$ & $+\mathrm{P}$ & $-\mathrm{P}$ & $+\mathrm{P}$ & $-\mathrm{P}$ & $+\mathrm{P}$ & $-\mathrm{P}$ \\
\hline B-69/N 104-7 (T) & 1.52 & $1.62 \mathrm{ad}$ & 0.64 & $0.88 \mathrm{ad}$ & 2.16 & $2.51 \mathrm{ad}$ & 0.42 & 0.54 \\
\hline B-69/N 114-7 (T) & 1.35 & $2.15 \mathrm{abcd}$ & 0.64 & $0.67 \mathrm{ad}$ & 1.98 & $2.82 \mathrm{acd}$ & 0.47 & 0.31 \\
\hline B-69/N 151-8 (T) & 1.82 & 1.79ad & 0.68 & $0.65 \mathrm{ad}$ & 2.50 & $2.44 \mathrm{ad}$ & 0.37 & 0.36 \\
\hline B-69/N 115-9 (T) & 1.79 & $1.56 \mathrm{a}$ & 0.95 & $0.90 \mathrm{ad}$ & 2.74 & 2.46ad & 0.53 & 0.57 \\
\hline B-69/N 331-8 (T) & 1.53 & $1.52 \mathrm{a}$ & 0.80 & $0.62 \mathrm{ad}$ & 2.33 & $2.14 \mathrm{ad}$ & 0.52 & 0.41 \\
\hline B-69/N 286-6 (T) & 1.26 & $2.34 \mathrm{abcd}$ & 0.80 & 1.19abcd & 2.06 & $3.53 \mathrm{abcd}$ & 0.63 & 0.51 \\
\hline B-69/N 170-9 (T) & 1.93 & $1.59 \mathrm{a}$ & 0.80 & $0.70 \mathrm{ad}$ & 2.73 & $2.28 \mathrm{ad}$ & 0.42 & 0.44 \\
\hline B-69/N 177-4 (P) & 1.62 & $0.34 \mathrm{bcd}$ & 0.70 & $0.32 \mathrm{bc}$ & 2.31 & $0.66 b c$ & 0.43 & $0.92 \mathrm{abcd}$ \\
\hline B-69/N 48-4 (P) & 1.63 & $0.50 \mathrm{bc}$ & 0.71 & $0.21 b c$ & 2.34 & $0.71 b c$ & 0.44 & 0.43 \\
\hline B-69/N 67-9 (P) & 1.86 & $0.22 \mathrm{bcd}$ & 0.87 & $0.22 b c$ & 2.72 & $0.44 b c$ & 0.47 & $0.97 \mathrm{abcd}$ \\
\hline B-69/N 110-6 (P) & 1.85 & $0.40 \mathrm{bc}$ & 0.80 & $0.16 b c$ & 2.65 & $0.56 b c$ & 0.43 & 0.40 \\
\hline B-69 (TP) & 1.79 & 0.58 & 1.00 & 0.21 & 2.79 & 0.79 & 0.56 & 0.37 \\
\hline WHP (VN) & 1.66 & 1.29 & 0.64 & 0.72 & 2.30 & 2.01 & 0.39 & 0.56 \\
\hline Kawali (VN) & 2.19 & 0.99 & 0.82 & 0.33 & 3.01 & 1.32 & 0.37 & 0.33 \\
\hline Numbu (TT) & 1.41 & 1.38 & 0.84 & 0.70 & 2.26 & 2.08 & 0.6 & 0.50 \\
\hline$P$ value & 0.889 & 0.00 & 0.980 & 0.00 & 0.976 & 0.00 & 0.121 & 0.001 \\
\hline CV (\%) & 34.56 & 30.46 & 41.85 & 25.84 & 35.47 & 25.69 & 22.18 & 33.17 \\
\hline LSD & - & 0.62 & - & 0.24 & - & 0.77 & - & 0.295 \\
\hline
\end{tabular}

Keterangan: $\mathrm{a}=$ berbeda nyata menurut uji lanjut LSD pada taraf 5\% dengan pembanding B-69; $\mathrm{b}=$ berbeda nyata menurut uji lanjut LSD pada taraf $5 \%$ dengan pembanding Numbu; $\mathrm{c}=$ berbeda nyata menurut uji lanjut LSD pada taraf $5 \%$ dengan pembanding WHP; $\mathrm{d}=$ berbeda nyata menurut uji lanjut LSD pada taraf 5\% dengan pembanding Kawali; $+\mathrm{P}=\mathrm{P}$ cukup; $-\mathrm{P}=\mathrm{P}$ rendah; TT $=$ tetua toleran; $\mathrm{TP}=$ tetua peka; $\mathrm{VN}=$ Varietas nasional 
bahwa pada kondisi $\mathrm{P}$ cukup, biomassa yang tinggi akan didukung oleh sistem perakaran seperti volume yang tebal, jumlah akar proteoid yang banyak dan diameter akar yang besar.

Tabel 6 menunjukkan bahwa pada kondisi $\mathrm{P}$ rendah karakter morfologi akar yang memiliki korelasi positif dengan biomassa secara berurutan adalah volume akar, panjang akar terpanjang, jumlah akar proteoid dan diameter akar terpanjang. Hal ini menunjukkan bahwa karakter tersebut dapat dijadikan sebagai karakter penting untuk seleksi adaptasi akar pada kondisi $\mathrm{P}$ rendah. Camacho et al. (2002) menyatakan bahwa karakter yang berkorelasi positif dengan hasil dapat dijadikan sebagai kriteria seleksi penting dalam program pemuliaan, seperti halnya dalam penelitian ini karakter morfologi akar berkorelasi positif dengan biomassa.

Tabel 5. Korelasi karakter morfologi akar terhadap biomassa pada kondisi P cukup

\begin{tabular}{|c|c|c|c|c|c|c|c|}
\hline & PAT & VA & DAT & PR & BKT & BKA & BKTO \\
\hline VA & 0.273 & & & & & & \\
\hline DAT & 0.140 & $0.3592 *$ & & & & & \\
\hline JAP & 0.016 & $0.4802 *$ & $0.5147^{*}$ & & & & \\
\hline BKT & 0.135 & $0.6803^{*}$ & $0.4293^{*}$ & $0.6241 *$ & & & \\
\hline BKA & 0.146 & $0.6314^{*}$ & $0.4477 *$ & $0.6978 *$ & $0.7625^{*}$ & & \\
\hline ВKTO & 0.148 & $0.7022 *$ & $0.4618 *$ & $0.6890 *$ & $0.9696 *$ & $0.8975^{*}$ & \\
\hline RAT & 0.067 & 0.097 & 0.119 & 0.201 & -0.164 & $0.4930 *$ & 0.075 \\
\hline
\end{tabular}

Keterangan: * = korelasi nyata; PAT = panjang akar terpanjang; VA = volume akar; DAT = diameter akar terpanjang; JAP = jumlah akar proteoid; $\mathrm{BKT}=$ bobot kering tajuk; $\mathrm{BKA}=$ bobot kering akar; $\mathrm{BKTO}=$ bobot kering total

Tabel 6. Korelasi karakter morfologi akar terhadap biomassa pada kondisi P rendah

\begin{tabular}{|c|c|c|c|c|c|c|c|}
\hline & PAT & VA & DAT & PR & BKT & BKA & BKTO \\
\hline $\mathrm{VA}$ & $0.7517 *$ & & & & & & \\
\hline DAT & $0.6898 *$ & $0.6687^{*}$ & & & & & \\
\hline JAP & $0.6839 *$ & $0.7128 *$ & $0.7194^{*}$ & & & & \\
\hline BKT & $0.7467 *$ & $0.8150 *$ & $0.7937^{*}$ & $0.7686^{*}$ & & & \\
\hline BKA & $0.8563 *$ & $0.8787^{*}$ & $0.6683^{*}$ & $0.7487^{*}$ & $0.8325^{*}$ & & \\
\hline BKTO & $0.8100 *$ & $0.8662 *$ & $0.7836^{*}$ & $0.7912 *$ & $0.9842 *$ & $0.9175^{*}$ & \\
\hline RAT & -0.228 & -0.189 & $-0.4597 *$ & $-0.2947 *$ & $-0.4761 *$ & -0.102 & -0.374 \\
\hline
\end{tabular}

Keterangan: $*$ = korelasi nyata; PAT = panjang akar terpanjang; VA = volume akar; DAT = diameter akar terpanjang; JAP = jumlah akar proteoid; $\mathrm{BKT}=$ bobot kering tajuk; $\mathrm{BKA}=$ bobot kering akar; $\mathrm{BKTO}=$ bobot kering total

\section{KESIMPULAN}

Terdapat perbedaan tanggap morfologi akar di antara galur-galur inbrida (RIL-F8) sorgum pada kondisi P rendah. Galur-galur toleran memiliki panjang akar terpanjang (41.33-61.87 cm), volume akar (8.87-12.87 mL), diameter akar terpanjang $(0.88-1.02 \mathrm{~mm})$ dan jumlah akar proteoid (2.4-4.0) yang lebih tinggi dibandingkan galur-galur peka pada kondisi $\mathrm{P}$ rendah. Karakter-karakter tersebut mendukung tingginya biomassa galur toleran pada kondisi $\mathrm{P}$ rendah, sehingga menjadi karakter penting untuk seleksi adaptasi akar pada kondisi P rendah.

\section{DAFTAR PUSTAKA}

Agustina, K., D. Sopandie, Trikoesoemaningtyas, D. Wirnas. 2010. Tanggap fisiologi akar sorgum (Sorghum bicolor L. Moench) terhadap cekaman aluminium dan defisiensi fosfor di dalam rhizotron. J Agron. Indonesia 38:88-94.

Bernardino, K.C., M.M. Pastina, C.B. Menezes, S.M. Desousa, L.S. Maciel, C.J. Geraldo, C.T. Guimaraes, B.A. Barros, L.D.C. E-Silva, P.C.S. Carneiro, R.E. Schaffert, L.V. Kochian, J.V. Magalhaes. 2019. The genetic architecture of phosphorus efficiency in sorghum involves pleiotropic QTL for root morphology and grain yield under low phosphorus aviability in the soil. BMC Plant Biology. 19:1-15.

Camacho, R., E. Malavolta, J. Guerrerro-Alves, T. Camacho. 2002. Vegetative growth of grain sorghum in response to phosphorus nutrition. Sci. Agricola. 6:771-776. 
Deng, Y., C. Men, S. Qiao, W. Wang, J. Gu, L. Liu, Z. Zhang, H. Zhang, Z. Wang, J. Yang. 2020. Tolerance to low phosphorus in rice varieties is conferred by regulation of root growth. Crop J. doi.org/10.1016/ j.cj.2020.01.002. (in press).

Gumayo, R., J.H. Chin, J. Pariasca-Tanaka, P. Pesaresi, S. Catausan, C. Dalid, I.Slamet-Loedin, E.M. TecsonMendoza, M. Wissuwa, S. Heuer. 2012. The protein kinase Pstol1 from tradisional rice confers tolerance of phosphorus deficiency. Nature. 488:535-542.

Jia, X., P. Liu, J.P. Lynch. 2018. Greater lateral root branching density in maize improve phosphorus acquisition from low phosphorus soil. J. Exp. Bot. 69:4961-4970.

Jiang, H., J. Zhang, Z. Han, J. Yang, C. Ge, Q. Wu. 2017. Revealing new insights into different phosphorusstarving response between two maize (Zea mays) inbred lines by transcriptomic and proteomic studies. Sci Rep. 7:1-9.

Lestari, T., Trikoesoemaningtyas, S.W. Ardie, D. Sopandie. 2017. Peranan fosfor dalam meningkatkan toleransi tanaman sorgum terhadap cekaman aluminium. J. Agron. Indonesia 45:43-48.

Luna, D.F., A.B.S. Pons, D. Bustos, E. Taleisnik. 2018. Early responses to Fe-defisiency distinguish Sorghum bicolor genotypes with contrasting alkalinity tolerance. Environmental and Experimental Botany. 155:165-176.

Marschner, H. 2012. Mineral Nutrition of Higher Plants 3rd ed. New York (US): Academic Press.

Miguel, M.A., J.A. Postma, J.P. Lynch. 2015, Phene synergism between root hair length and basal root growth angle for phosphorus acquisition. Plant Physiol. 167:1430-1439.

Momongan, J.D., Trikoesoemaningtyas, D. Wirnas, D. Sopandie. 2019. Potensi hasil dan toleransi galurgalur inbrida sorgum pada tanah dengan hara fosfor rendah. J. Agron. Indonesia 47:39-46.

Niu, Y.F., R.S. Chai, G.L. Jin, H. Wang, C.X. Tang, Y.S. Zhang. 2013. Response of root architecture development to low phosphorus availability: a review. Ann Bot. 112:391-408.

Nguyen, V.L., J. Stangoulis. 2019. Variation in root system architecture and morphology of two wheat genotypes is a predictor of their tolerance to phosphorus deficiency. Acta Physiol Plant. 41:1-13.
Nobile, C., D. Houben, E. Michel, S. Firmin, H. Lambers, E. Kandele, M.P. Faucon. 2019. Phosphorus aquisition strategies of canola, wheat and barley in soil amended with sewage sludges. Sci Rep. 9:1-11.

Ongom, P.O., J.J. Volenec, G. Ejeta. 2016. Selection for drought tolerance in sorghum using desiccants to simulate post-anthesis drought stress. Field Crops Res. 198:312-321.

Péret, B., T. Desnos, R. Jost, S. Kanno, O. Berkowitz, L. Nussaume. 2014. Root architecture responses: in search of phosphate. Plant Physiol. 166:1713-1723.

Rath, M., J. Salas, B. Parhy, R. Norton, H. Menakuru, M. Sommerhalter, G. Hatlstad, J. Kwon, D.L. Allan, C.P. Vance. 2010. Identification of genes induced in proteoid roots of white lupin under nitrogen and phosphorus deprivation, with functional characterization of a formamidase. Plant Soil. 334:137-150.

Rui-Dong, H. 2018. Research progress on plant tolerance to soil salinity and alkalinity in sorghum, J. Integ. Agric. 17:739-746.

Shane, M.W., H. Lambers. 2005. Cluster roots: a curiosity in context. Plant Soil. 274:101-125.

Vanderlip, R.L., H.E. Reeves. 1972. Growth stage of sorghum. Agron J. 64:13-16.

Vejchasarn, P., P.L. Jonathan, K.M. Brown. 2016. Genetic variability in phosphorus responses of rice root phenotypes. Rice. 9:1-16.

Wang, X., W. Ding, H. Lambers. 2019. Nodulation pomotes cluster-root formation in Lupinus albus under low phosphorus conditions. Plant Soil. 439:233-242.

Wasaki, J., J. Sakaguchi, T. Yamamura, S. Ito, T. Shinano, M. Osaki, E. Kendeler. 2018. P and N deficiency change the relative abundance and function of rhizosphere microorganisms during cluster root development of white lupin (Lupinus albus L). Soil Sci. Plant Nutr. 64:686-696

Whitney, D. 1998. Grain Sorghum Production Handbook. Kansas (US): Kansas State University Agricultural Experiment Station and Cooperative Extension Service. 